Review

\title{
Surface Display Technology for Biosensor Applications: A Review
}

\author{
Min Park 1,2 (D) \\ 1 Major in Materials Science and Engineering, Hallym University, Chuncheon, Gangwon-do 24252, Korea; \\ minpark@hallym.ac.kr; Tel.: +82-33-248-2363 \\ 2 Integrative Materials Research Institute, Hallym University, Chuncheon, Gangwon-do 24252, Korea
}

Received: 20 March 2020; Accepted: 11 May 2020; Published: 13 May 2020

\begin{abstract}
Surface display is a recombinant technology that expresses target proteins on cell membranes and can be applied to almost all types of biological entities from viruses to mammalian cells. This technique has been used for various biotechnical and biomedical applications such as drug screening, biocatalysts, library screening, quantitative assays, and biosensors. In this review, the use of surface display technology in biosensor applications is discussed. In detail, phage display, bacterial surface display of Gram-negative and Gram-positive bacteria, and eukaryotic yeast cell surface display systems are presented. The review describes the advantages of surface display systems for biosensor applications and summarizes the applications of surface displays to biosensors.
\end{abstract}

Keywords: biosensors; surface display; molecular recognition layer; molecular display; phage display; bacterial surface display; yeast cell surface display

\section{Introduction}

A biosensor is an analytical device that selectively provides a quantitative response to a single or several analytes among thousands of compounds in complex samples such as physiological fluids including blood, cerebrospinal fluid, urine, and saliva [1,2]. As shown in Figure 1, biosensors are generally composed of three main parts: a molecular recognition layer, a transducer, and a signal generator [3]. In general, the molecular recognition layer is produced by the immobilization of a bioreceptor on the surface of the transducer to allow specific binding of a target analyte [1,4]. After the bioreceptor binds the analyte, a measurable signal can be generated by the transducer through changes in the thickness, weight, refractive index, or the structure of the molecule via chemical reaction [5-13]. The molecular recognition layer is especially important for achieving specific detection in biomedical analyses. To achieve specific and strong binding of the analyte to the biosensor, various bioreceptors such as antibodies, aptamers, enzymes, and peptides have been used [14-19]. The physiological fluids mentioned above are complex mixtures of thousands or millions of ions, proteins, nucleic acids, and cells; therefore, the specific binding of a target analyte in physiological fluid is one of the most important challenges for increasing the sensitivity and reducing the noise of biosensors [20].

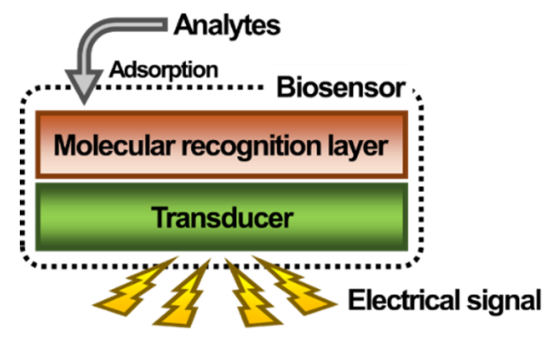

Figure 1. Schematic of a biosensor. 
Cells are the basic units of all organisms, including humans, and are enclosed within a membrane. The cell membrane comprises various membrane proteins and other biomolecules that interact via covalent or non-covalent bonds [21,22]. The se membrane proteins play important roles in cell signaling, influencing the enzymatic environment, molecular transport, and cell identification [23-25]. Among the functions of membrane proteins, receptor proteins can recognize signaling molecules, and this recognition is very similar to the role of the molecular recognition layer in biosensors [26]. By using these membrane proteins and protein engineering, the designed protein can be displayed on the cell surface. Unlike the general protein expression mechanism, membrane protein-linked proteins are anchored and displayed on the cell surface, and this surface display technology can be utilized for translocation, biocatalysis, drug screening, library screening, etc., [27-30]. Affinity proteins are the main targets of surface displays, and these proteins can potentially be applied as molecular recognition layers. In addition, these surface display technologies has advantage that the surface displaying particles or cells can be act as a biological matrix to detect the target analyte from. In this review, various types of surface display technologies are introduced, and their application in biosensors is discussed. In detail, phage displays, bacterial surface displays, and eukaryotic cell surface displays are introduced, and the applications of these systems to biosensors are summarized. This review provides a brief and concise discussion of the application of surface display technology in the molecular recognition layer of biosensors.

\section{Phage Display-Based Biosensors}

Surface expression systems were initially based on phage display systems. Phages are viruses that infect bacterial cells. Phage display was first introduced by Smith, when he inserted a foreign DNA fragment of a peptide library into the minor coat protein of the filamentous bacteriophage, pIII [31]. For the phage display of filamentous bacteriophage, the major coat protein pVIII and minor coat proteins pIII and pVI are the major recombinant targets [32]. Various libraries have been displayed on phages, and library-displaying phages can be selectively screened using biopanning [33-35]. Phage display has been widely used for affinity screening from random libraries because phage libraries have high diversity. The affinity peptides from library screening can be utilized as bioreceptors for the molecular recognition layer [36,37].

Various studies have investigated the application of phage display systems to biosensors. In most studies, random peptides or $\mathrm{scFv}$ antibodies libraries were displayed on the phage particles and screened to find the affinity peptide or protein by biopanning. After biopanning, the selected peptides or phage particles were used to form a molecular recognition layer for biosensor applications. The biosensor applications of phage display systems and their performance are summarized in Table 1.

Table 1. Examples of phage display-based biosensors and their performance.

\begin{tabular}{|c|c|c|c|c|c|}
\hline $\begin{array}{l}\text { Type of } \\
\text { Library }\end{array}$ & Affinity Target & Detection Mode & Performance & Assay Time & Ref. \\
\hline \multirow{8}{*}{ Peptide } & \multirow{2}{*}{ Troponin I } & QCM & $\begin{array}{l}\text { Sensitivity: } 18 \mathrm{~Hz} /(\mu \mathrm{g} / \mathrm{mL}) \\
\text { LOD: } 0.11 \mu \mathrm{g} / \mathrm{mL}\end{array}$ & - & \multirow{2}{*}{ [38] } \\
\hline & & EIS & $\begin{array}{l}\text { Sensitivity: } 0.3 \text { impedance } /(\mu \mathrm{g} / \mathrm{mL}) \\
\text { LOD: } 0.34 \mu \mathrm{g} / \mathrm{mL}\end{array}$ & $1 \mathrm{~h}$ & \\
\hline & \multirow{2}{*}{ Aminotransferase } & QCM & $\begin{array}{l}\text { Sensitivity: } 8.9 \mathrm{~Hz} /(\mu \mathrm{g} / \mathrm{mL}) \\
\text { LOD: } 60 \mathrm{ng} / \mathrm{mL}\end{array}$ & - & \multirow{2}{*}{ [39] } \\
\hline & & EIS & $\begin{array}{l}\text { Sensitivity: } 142 \text { impedance } \% /(\mu \mathrm{g} / \mathrm{mL}) \\
\text { LOD: } 92 \mathrm{ng} / \mathrm{mL}\end{array}$ & $1 \mathrm{~h}$ & \\
\hline & S. aureus & Colorimetry & LOD: $19 \mathrm{CFU} / \mathrm{mL}$ & $30 \mathrm{~min}$ & [40] \\
\hline & Mouse EEG signal & EIS & Contact impedance: $7.4 \mathrm{k} \Omega$ & - & [41] \\
\hline & Glucose & Electrochemistry & Sensitivity: $107 \mu \mathrm{A} / \mathrm{mM} \cdot \mathrm{cm}^{2}$ LOD: $10 \mu \mathrm{M}$ & $<10 \mathrm{~s}$ & [42] \\
\hline & $\beta$-galactosidase & QCM & $K_{d}=1.7 \mathrm{nM}$ & $100 \mathrm{~s}$ & [43] \\
\hline $\mathrm{scFv}$ & L. monocytogenes & SPR & LOD: $2 \times 10^{6} \mathrm{cfu} / \mathrm{mL}$ & - & [44] \\
\hline
\end{tabular}


Wu et al. developed a peptide-based molecular recognition layer using electrochemical impedance spectroscopy (EIS) and a quartz crystal microbalance (QCM) biosensor to detect aminotransferase (ALT) and troponin I (TnI) (Figure 2a) [38,39,45]. Peptides with the target affinity were selected by biopanning from the random peptide library displaying the M13 phage and immobilized on the biosensor surface as a molecular recognition layer. By using the affinity peptides, a QCM and EIS biosensors were used to detect ALT and TnI. In these studies, the displayed phage was only used to screen the affinity peptide for specific analyte binding, and bacteriophage particles were not directly applied to the biosensors.

Liu et al. developed a colorimetric biosensor by utilizing the pVIII protein isolated from a phage (Figure 2b [40]. The Staphylococcus aureus binding phage with the $\mathrm{f} 8 / 8$ landscape phage library was selected, and the pVIII protein of the selected phage was isolated and purified. The isolated specific pVIII protein was immobilized on amine-functionalized gold nanoparticles (GNPs) via EDC/NHS chemistry, and the protein-immobilized gold nanoparticles were utilized for the detection of $S$. aureus by colorimetry. Rapid and one-step biosensing was realized via the developed method. In these studies, the major coating proteins of the phages were exploited for biosensing.

In another approach, the entire M13 phage particle was utilized for the fabrication of a carbon nanotube (CNT)-based nanomesh [41] and applied to enzyme-based electrochemical biosensors (Figure 2c) [42]. In this method, single-walled carbon nanotube (SWNT)-binding phages were selected from phages displaying the $\mathrm{pVIII}$ peptide library by biopanning. After affinity confirmation, a conductive and flexible nanomesh was assembled by using the phage particles and SWNTs [41]. The fabricated nanomesh was integrated into a flexible microarray and implanted in the skull of a mouse. In comparison with the bare electrode, the microarray allowed the detection of high-density electroencephalography (EEG) signals and significantly increased high-frequency brain signal (HFBS) levels. This phage display-based CNT nanomesh was applied to the fabrication of an enzyme-based biosensor employing direct electron transfer (DET) [42]. This DET biosensor based on phage display was confirmed to be suitable for the detection of glucose, cholesterol, lactate, peroxide, galactose, and catechol/catechol amine by changing the immobilized enzymes.

Nanduri et al. [43] utilized phage particles as molecular recognition elements. Phages with $\beta$-galactosidase affinity were selected and whole viral particles were immobilized on the surface of the QCM biosensor by simple physical adsorption. The dissociation constant $\left(K_{d}\right)$ for the molecular recognition layer based on phage display was similar to that of the monoclonal antibody-based layer. From this study, phage particles were confirmed to be suitable components of the molecular recognition layer.

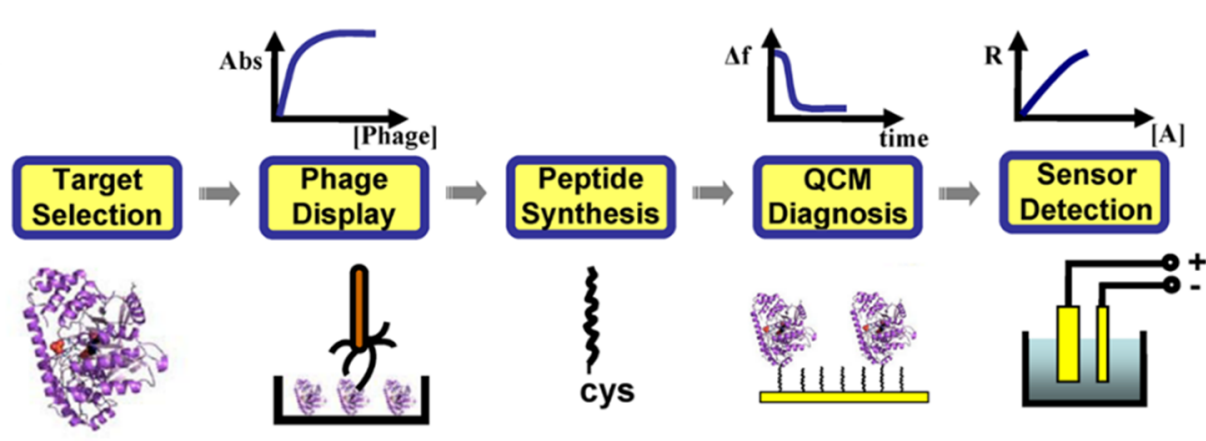

(a)

Figure 2. Cont. 




(b)

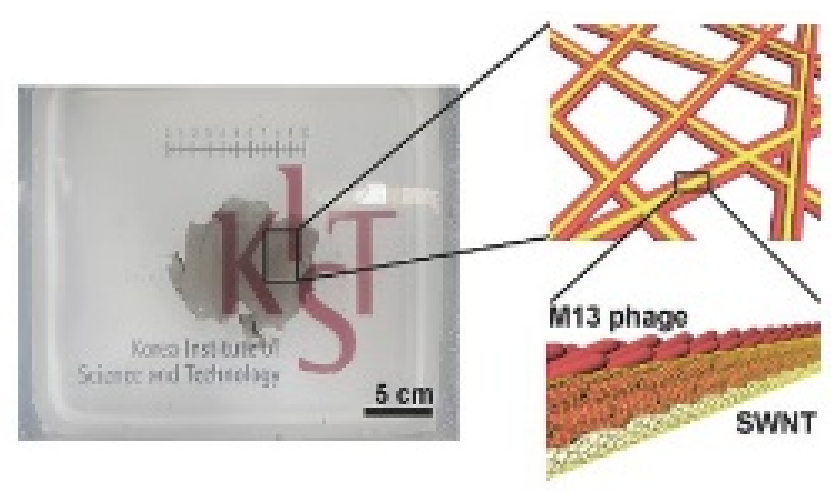

(c)

Figure 2. Examples of phage display-based biosensors. (a) Bioreceptor screening and application to a biosensor using peptide library-displaying bacteriophage. Reproduced with permission from [38]. Copyright (2010). Plos. (b) Fabrication of pVIII protein from phage-immobilized gold nanoparticles (GNP). Reproduced with permission from [40]. Copyright (2016) Elsevier. (c) Carbon nanotube (CNT) nanomesh using the M13 phage as a biological glue. Reproduced with permission from [42]. Copyright (2016) Wiley and Sons, Inc.

Unlike the studies described above, Nanduri et al. displayed antibodies and utilized phage particles to detect Listeria monocytogenes (L. monocytogenes) using an SPR biosensor [44]. A single-chain variable fragment $(\mathrm{scFv})$ displaying phage particles with specific affinity for L. monocytogenes was 
selected from a random scFv-displaying phage library [46] and immobilized on the surface of the SPR biosensor to form a molecular recognition layer.

\section{Bacterial Surface Display for Biosensor Applications}

Phage display technology has been widely used for the expression of libraries, antibodies, and specific ligands. However, the fusion of larger-sized targets in phage display systems is restricted by size limitations $[47,48]$. Cell surface displays based on bacterial cells offer the advantages of high yield, high productivity, and capability to display large-sized targets [48-51]. Bacteria are prokaryotes and biological cells, and can proliferate by binary fission. Because of these advantages, bacterial cells are the systems most frequently used for the expression of recombinant proteins [52]. For this reason, bacterial surface display is also actively researched and applied to biosensors [53]. In this section, bacterial surface displays for biosensor applications are discussed, and examples are presented.

\subsection{Gram-Negative Bacteria}

Gram-negative bacteria are not stained by crystal violet; the cell envelopes of Gram-negative bacteria are composed of an inner membrane, peptidoglycan, and outer membrane [54]. Among Gram-negative bacteria, Escherichia coli (E. coli) has been widely used because of its genetic availability and high transformation efficiency $[29,55]$. E. coli cells have been employed in various surface display strategies. Outer membrane proteins, lipoproteins, fimbria proteins, and flagellar proteins have been used for the surface display of target proteins on cells [56-59]. For the successful surface display of Gram-negative bacteria, the expressed proteins should cross the inner membrane and become anchored on the outer membrane [60]. For these reasons, various secretion mechanisms have been used for Gram-negative surface display [51,61].

Bacterial surface display systems offer the possibility of displaying larger molecules, including active enzymes, as their main advantage. In this respect, various studies of Gram-negative bacterial surface displays are related to the display of active enzymes. Such enzyme-displaying bacteria are valuable not only as molecular recognition molecules, but also as signal-generating molecules. Electrochemical biosensors can be fabricated based on these enzyme-surface-displaying bacteria. In addition, affinity molecules such as Z-domain or streptavidin can also be displayed on the surface of Gram-negative bacterial cells. By controlling the orientation of the displayed affinity molecules, improved performance of the biosensor was obtained. The biosensor applications of Gram-negative bacterial surface display systems are summarized in Table 2 .

Table 2. Examples of bacterial surface displays for biosensor applications.

\begin{tabular}{|c|c|c|c|c|c|c|c|}
\hline Type of Target & $\begin{array}{c}\text { Displayed } \\
\text { Target }\end{array}$ & $\begin{array}{l}\text { Display } \\
\text { System }\end{array}$ & $\begin{array}{l}\text { Detection } \\
\text { Mode }\end{array}$ & Analyte & Performance & $\begin{array}{l}\text { Assay } \\
\text { Time }\end{array}$ & Ref \\
\hline \multirow{9}{*}{ Enzyme } & \multirow{6}{*}{$\mathrm{OPH}$} & \multirow{3}{*}{ Lpp-OmpA } & \multirow{3}{*}{ Potentiometry } & Paraoxon & LOD: $2 \mu \mathrm{m}$ & \multirow{3}{*}{$10 \mathrm{~min}$} & \multirow{3}{*}{ [62] } \\
\hline & & & & $\begin{array}{c}\text { Methyl } \\
\text { parathion }\end{array}$ & LOD: $2 \mu \mathrm{M}$ & & \\
\hline & & & & Diazinon & $\begin{array}{l}\text { LOD, diazinon: } \\
5 \mu \mathrm{M}\end{array}$ & & \\
\hline & & \multirow{5}{*}{ INP } & \multirow{3}{*}{ Amperometry } & Paraoxon & LOD: $9.0 \mathrm{nM}$ & \multirow{3}{*}{$5 \mathrm{~s}$} & \multirow{3}{*}[63]{} \\
\hline & & & & Parathion & LOD: $10.0 \mathrm{nM}$ & & \\
\hline & & & & $\begin{array}{c}\text { Methyl } \\
\text { parathion }\end{array}$ & LOD: $15 \mathrm{nM}$ & & \\
\hline & GDH & & Amperometry & Glucose & LOD: $4 \mu \mathrm{M}$ & $2 \mathrm{~s}$ & [64] \\
\hline & GluDH & & Amperometry & Glutamate & LOD: $2 \mu \mathrm{M}$ & - & [65] \\
\hline & Laccase & inaQ-N & Voltammetry & Catechol & $\begin{array}{c}\text { LOD: } 0.1 \mu \mathrm{M} \\
\text { Linear range: } \\
0.5-300 \mu \mathrm{M}\end{array}$ & - & [66] \\
\hline
\end{tabular}


Table 2. Cont.

\begin{tabular}{|c|c|c|c|c|c|c|c|}
\hline Type of Target & $\begin{array}{c}\text { Displayed } \\
\text { Target }\end{array}$ & $\begin{array}{l}\text { Display } \\
\text { System }\end{array}$ & $\begin{array}{l}\text { Detection } \\
\text { Mode }\end{array}$ & Analyte & Performance & $\begin{array}{l}\text { Assay } \\
\text { Time }\end{array}$ & Ref \\
\hline \multirow{10}{*}{$\begin{array}{l}\text { Affinity peptide } \\
\text { or protein }\end{array}$} & GBP & FadL & \multirow{2}{*}{ SPR } & \multirow{2}{*}{$\begin{array}{l}\text { Biotinylated } \\
\text { HRP }\end{array}$} & \multirow{2}{*}{$\begin{array}{c}0.62 \% \text { SPR } \\
\text { angle change }\end{array}$} & \multirow{2}{*}{$20 \mathrm{~min}$} & \multirow{2}{*}{67} \\
\hline & $\mathrm{cSA}$ & OprF & & & & & \\
\hline & ZBP & \multirow{2}{*}{ OmpC } & \multirow{2}{*}{ Fluorescence } & $\mathrm{Zn}^{2+}$ & $\begin{array}{c}0.74 \mathrm{mg} / \mathrm{g} \\
\text { adsorption }\end{array}$ & \multirow{2}{*}{$4 \mathrm{~h}$} & \multirow[t]{2}{*}[68]{} \\
\hline & CBP & & & $\mathrm{Cu}^{2+}$ & $\begin{array}{c}0.75 \mathrm{mg} / \mathrm{g} \\
\text { adsorption }\end{array}$ & & \\
\hline & \multirow{4}{*}{ Z-domain } & \multirow{4}{*}{ AIDA-I } & \multirow{4}{*}{ SPR } & myoglobin & $\begin{array}{c}\text { 10-fold } \\
\text { improved LOD }\end{array}$ & $1 \mathrm{~h}$ & [69] \\
\hline & & & & CRP & $\begin{array}{l}\text { 5-fold improved } \\
\text { cut-off value }\end{array}$ & $40 \mathrm{~min}$ & [70] \\
\hline & & & & CRP & $\begin{array}{c}\text { 100-fold } \\
\text { improved LOD }\end{array}$ & $35 \mathrm{~min}$ & [71] \\
\hline & & & & hIgG & $\begin{array}{c}\text { 10-fold } \\
\text { improved LOD }\end{array}$ & $40 \mathrm{~min}$ & [72] \\
\hline & \multirow{2}{*}{ affibody } & \multirow{2}{*}{$\mathrm{ABP}$} & SPR & $\mathrm{TNF}-\alpha$ & $K_{d}: 0.77 \mathrm{nM}$ & $20 \mathrm{~min}$ & [73] \\
\hline & & & SPR & ErbB3 & $K_{d}: 0.7 \mathrm{nM}$ & $11 \mathrm{~min}$ & [74] \\
\hline
\end{tabular}

Richins et al. displayed active organophosphorus hydrolase (OPH) on the surface of E. coli through the Lpp(Braun's lipoprotein)-OmpA (outer membrane protein A) fusion system for parathion and paraoxon degradation [75] and Mulchandani et al. fabricated a biosensor based on immobilized OPH displaying E. coli on a pH electrode (Figure 3a) [62]. After optimization, the fabricated biosensor was used to measure the concentration of organophosphates (OPs), i.e., paraoxon, methyl parathion, and diazinon. The limit of detection (LOD) for all analytes was lower than $5 \mu \mathrm{M}$, which is comparable to those of enzyme-based biosensors. Tang et al. [76] achieved the surface display of OPH using ice nucleation protein (INP) and applied this system to an electrochemical biosensor [63]. OPH surface-displaying E. coli cells were immobilized on the electrode with mesopore carbons and the concentration of the OPs (paraoxon, parathion, and methyl parathion) was measured by amperometry using the surface-displaying E. coli cell-based biosensor. From the measurement, the linear detection range and LOD were calculated to be $0.05-25 \mu \mathrm{M}$ and $9.0 \mathrm{nM}$ for paraoxon; $0.05-25 \mu \mathrm{M}$ and $10.0 \mathrm{nM}$ for parathion; and $0.08-30 \mu \mathrm{M}$ and $15.0 \mathrm{nM}$ for methyl parathion, respectively.

Liang et al. fabricated an electrochemical biosensor by using a bacterial surface display (Figure 3d) [64,65]. First, glucose dehydrogenase (GDH) was surface displayed on the surface of E. coli cells by using INP [64]. Surface-displayed E. coli cells were immobilized on the surface of a glassy carbon electrode (GCE). An amperometric glucose biosensor was fabricated by employing the E. coli cell-immobilized electrode. The LOD for glucose was calculated to be $4 \mu \mathrm{M}$, and this glucose biosensor was confirmed to be applicable to real samples. Glutamate dehydrogenase (GluDH) was surface displayed on the outer membrane of $E$. coli cells using INP, and an amperometric glutamate biosensor was fabricated using surface-displayed E. coli cells [65]. From the glutamate measurement, the LOD of the fabricated biosensor was calculated to be $2 \mu \mathrm{M}$. 


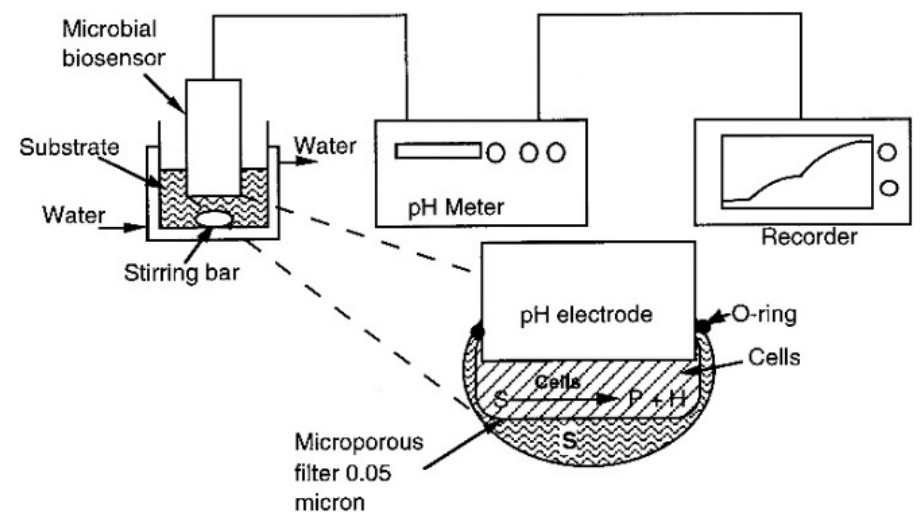

(a)
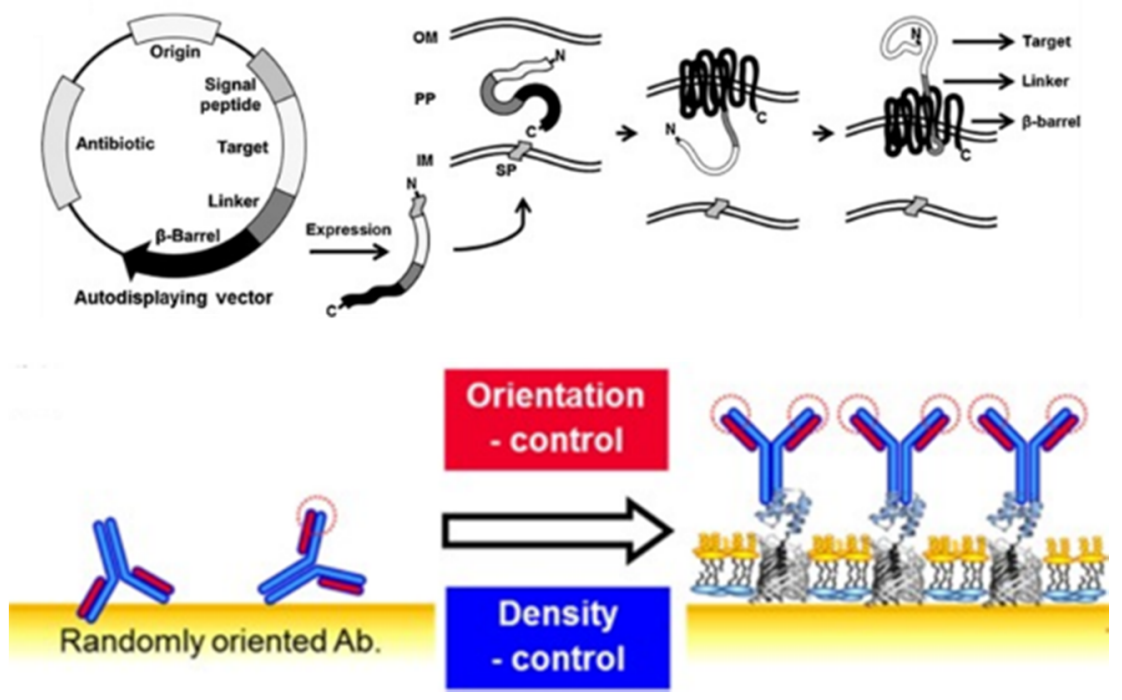

(b)

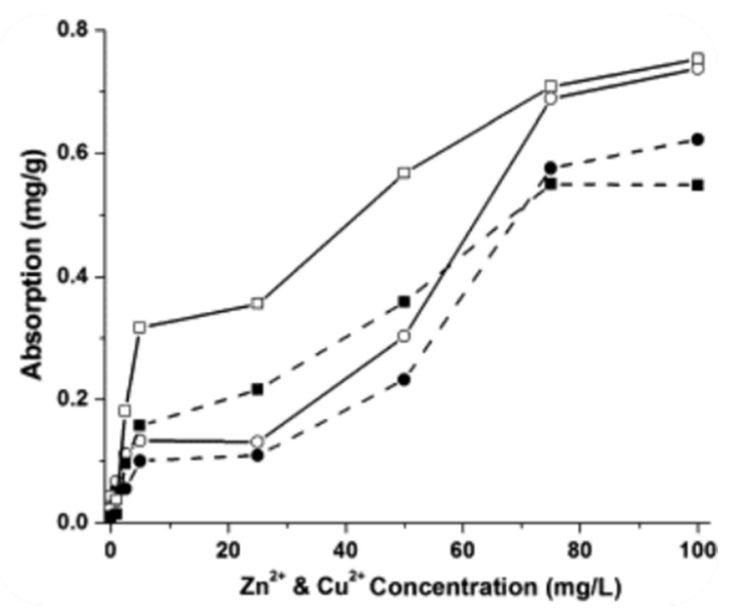

(c)

Figure 3. Cont. 

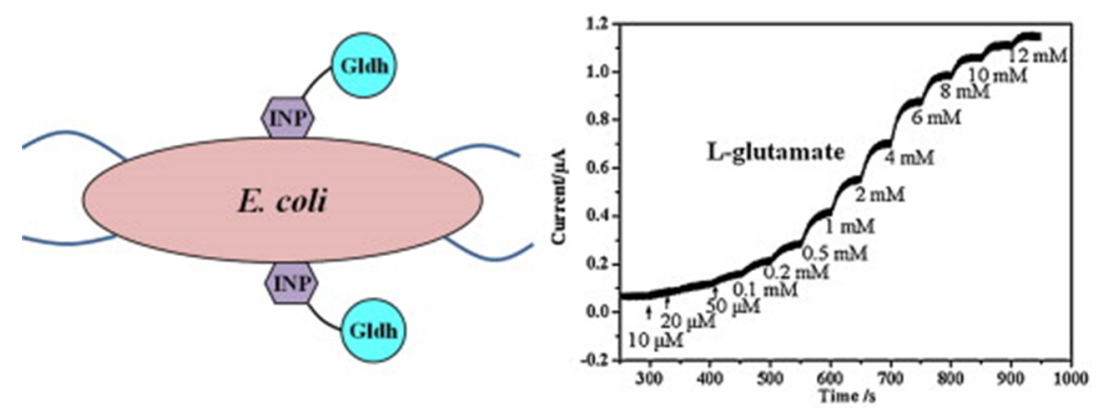

(d)

Figure 3. Biosensors based on Gram-negative bacterial surface display. (a) pH meter based on surface-displayed immobilized E. coli. Reproduced with permission from [62]. Copyright (1998) American Chemical Society. (b) Autodisplay of Z-domains and orientation control of the immunoaffinity layer based on autodisplayed Z-domains. Reproduced with permission from [9]. Copyright (2018) Elsevier. (c) Bioadsorption of heavy metal ions by surface-displayed E. coli cells: E. coli cells with (line) and without (dashed-line) surface-displaying vector were induced by $\mathrm{Zn}^{2+}$ (circle) and $\mathrm{Cu}^{2+}$ (square). Reproduced with permission from [68]. Copyright (2012) Elsevier. (d) Amperometric glutamate biosensor based on surface-displayed E. coli cells. Reproduced with permission from [65]. Copyright (2015) Elsevier.

Zhang et al. fabricated a voltammetric biosensor based on the surface display technology [66]. In this study, laccase was surface displayed through the INP variant (inaQ-N), and surface-displayed cells were immobilized on the surface of the electrode to fabricate the biosensor. The optimal conditions for catechol detection, including the cell loading, $\mathrm{pH}$, and scan rate were $4 \times 10^{8}$ cells, 3.0, and $100 \mathrm{mV}$ $\mathrm{S}^{-1}$, respectively. The linear range and LOD for catechol detection were calculated to be $0.5,300.0$ and $0.1 \mu \mathrm{M}$, respectively. In addition, the fabricated biosensor based on the surface display technology was confirmed to be suitable for the detection of catechol in real samples, red wine, and tea.

A dual surface display employing a gold-binding peptide (GBP) and core streptavidin (cSA) on the surface of E. coli was investigated by Park et al. [67]. In that study, GBP was surface displayed via FadL and utilized for the immobilization of surface-displayed E. coli cells on the gold surface of the SPR biosensor. cSA was surface displayed via OprF and used as the analyte recognition molecule. By utilizing the dual surface display system, whole E. coli cells were immobilized on the surface of the SPR biosensor to form a molecular recognition layer, and biotinylated HRP was detected.

Ravikumar et al. developed a bacterial cell-based fluorescence biosensor for heavy metal (zinc and copper) detection [68]. Green fluorescent protein (GFP) and red fluorescent protein (RFP) were expressed by induction with $\mathrm{Zn}^{2+}$ and $\mathrm{Cu}^{2+}$, respectively, and the fluorescence biosensor was fabricated based on the whole $E$. coli cell. This biosensor was extended by using the surface display of a zinc binding peptide (ZBP) and copper binding protein $(\mathrm{CBP})$ by outer membrane protein $\mathrm{C}(\mathrm{OmpC})$ (Figure 3c).

Autodisplay technology, a type of surface display for Gram-negative bacteria, has been developed based on the secretion mechanism of the autotransporter family proteins, where the expressed protein does not require any artificial treatment to pass through the inner membrane $[1,77,78]$. This technology also has been used to display affinity proteins, enzymes, libraries, and other species, and has been utilized in various applications including biosensors, biocatalysts, drug screening $[27,79,80]$. Jose et al. expressed immunoglobulin(Ig) G binding Z-domains [81] on the outer membrane of E. coli using autodisplay technology by utilizing the adhesion involved in diffuse adherence (AIDA-I), and applied this system to signal amplification in a SPR biosensor (Figure 3b) [69]. By signal amplification, the LOD for cardiac myoglobin detection was improved 10-fold compared to that without amplification. The Z-domains autodisplaying E. coli cells were immobilized on the SPR biosensor to construct a molecular recognition layer [70]. From the detection of C-reactive protein (CRP), an acute phase 
inflammatory biomarker, the cut-off value was calculated to be improved by 5 -fold. Because Z-domains can bind the $F_{c}$ region of IgG, orientation control can be realized and the performance of the immunosensor can be improved [1]. The outer membrane of Z-domains autodisplaying E. coli was isolated by lysozyme and Triton X-100 treatments [82] and layered on a 2-dimensional substrate [83]. This outer membrane layer with autodisplayed Z-domains was used as the immunoaffinity layer of a SPR biosensor after antibody treatment [71,72]. The performance of the SPR biosensor for detection of CRP and human IgG (hIgG) was improved by 100-fold and 10-fold through orientation control based on autodisplay technology, respectively. In addition, this immunoaffinity layer based on autodisplay technology could be reused after regeneration by acid treatment [84].

\subsection{Gram-Positive Bacteria}

The cell envelope of Gram-positive bacteria is composed of a plasma membrane and a thick outer peptidoglycan layer that is stained by crystal violet $[54,85]$. Because of the thick and rigid peptidoglycan layer, Gram-positive bacteria are considered to be suitable for cell-based applications such as whole-cell catalysts and whole-cell adsorbents [29]. For this reason, the surface display of Gram-positive bacteria has also been actively studied and applied in various fields, including biosensors [86,87]. Unlike Gram-negative bacterial surface display, most Gram-positive surface-displaying proteins are immobilized on the cell wall by covalent bonding [51,86].

Kronqvist et al. developed a screening system utilizing both phage display and bacterial surface display of Gram-positive cells [73]. To select the affinity protein (affibody) with tumor necrosis factor-alpha (TNF- $\alpha$ ), pre-enrichment was performed in one round of screening using a phage-displayed library. After screening, the staphylococcal display vector containing albumin-binding protein (ABP) from streptococcal protein $\mathrm{G}$ was constructed using the sequences from pre-enrichment. After vector transformation into Staphylococcus carnosus, surface-displaying cells with TNF- $\alpha$ affinity were selected by sorting using flow cytometry. Selected surface-displaying cells were immobilized on the SPR biosensor to determine the $K_{d}$ values. A similar approach was used to screen the affibody with ErbB3, an epidermal growth factor of transmembrane tyrosine kinase receptor [74]. From the SPR biosensor analysis, the $K_{d}$ and $K_{a}$ (association constant) values were calculated to be $0.7 \mathrm{nM}$ and $1.9 \times 10^{6} \mathrm{M}^{-1} \cdot \mathrm{s}^{-1}$, respectively. In those studies, staphylococcal surface-displaying affibodies were applied to the SPR biosensor, not for the fabrication of surface display-based biosensors, but for calculation of the affinity constant of screened affibodies. The molecular recognition layer was constructed based on the immobilized staphylococcal surface-displaying cells, and biosensing of target analytes could be accomplished.

\section{Eukaryotic Yeast Cell Surface Display for Biosensor Applications}

Yeasts are eukaryotic, unicellular microorganisms that are encapsulated within rigid cell walls, where the cell walls are mainly composed of mannoproteins and $\beta$-glucan [88]. For the surface display of a target protein on the surface of yeast cells, glycosylphosphatidylinositol (GPI)-anchored proteins such as glucanase-extractable mannoproteins, including agglutinin and flocculin, have been widely utilized $[22,89]$. In comparison with phage display and bacterial surface display, yeast cell surface display is advantageous in terms of safety and genetic engineering [90,91]. Yeast cells are widely used in the food and pharmaceutical industries because of their safety. In addition, yeast cells are eukaryotic cells that allow folding, disulfide isomerization, and glycosylation of expressed homologous proteins, especially complex eukaryotic proteins [92]. The se surface-engineered yeasts are also called "arming yeasts" $[93,94]$.

Yeast surface display systems offer the possibility of displaying complex eukaryotic proteins on the surface of safe microorganisms, i.e., yeast. Various types of proteins, such as fluorescent proteins, affinity proteins, and enzymes, have been displayed on yeast cell surfaces. Yeast cell surfaces displaying fluorescent proteins have been applied in optical biosensors, and enzyme surface displaying yeast 
cells were applied to electrochemical and optical biosensors. The biosensor applications of yeast cell surface displays are summarized in Table 3.

Table 3. Examples of yeast cell surface displays for biosensor applications.

\begin{tabular}{|c|c|c|c|c|c|}
\hline $\begin{array}{l}\text { Displayed } \\
\text { Target }\end{array}$ & Detection Mode & Analyte & Performance & Assay Time & Ref \\
\hline GFP & \multirow{4}{*}{ Fluorescence } & Glucose & \multirow{3}{*}{$\begin{array}{l}\text { Available for monitoring the presence } \\
\text { of analyte }\end{array}$} & - & [95] \\
\hline $\begin{array}{l}\text { GFP, } \\
\text { BFP }\end{array}$ & & Glucose & & - & [96] \\
\hline $\begin{array}{l}\text { ECFP, } \\
\text { EYFP }\end{array}$ & & $\begin{array}{l}\text { Phosphate, } \\
\text { ammonium ion }\end{array}$ & & - & [97] \\
\hline EGFP & & Protein expression & $\begin{array}{l}\text { Simultaneous displaying for protein } \\
\text { expression monitoring }\end{array}$ & - & [98] \\
\hline GOx & Voltammetry & Glucose & $\begin{array}{c}\text { LOD: } 0.05 \mathrm{mM} \\
\text { Linear range: } 0.1-14 \mathrm{mM}\end{array}$ & $20 s$ & [99] \\
\hline \multirow{3}{*}{$\mathrm{AChE}$} & Spectrophotometry & Paraoxon & $\begin{array}{c}\text { LOD: } 0.49 \mathrm{nM} \\
\text { Linear range: } 1.8 \mathrm{nM}-36.3 \mu \mathrm{M}\end{array}$ & \multirow{2}{*}{$15 \mathrm{~min}$} & \multirow{2}{*}{ [100] } \\
\hline & & Parathion & $\begin{array}{c}\text { LOD: } 12.8 \mathrm{nM} \\
\text { Linear range: } 17 \mathrm{~nm}-34.4 \mu \mathrm{M}\end{array}$ & & \\
\hline & Fluorescence & Paraoxon & $\begin{array}{c}\text { LOD: } 0.033 \mathrm{fM} \\
\text { Linear range: } 0.1 \mathrm{fM}-0.1 \mathrm{nM}\end{array}$ & $1.5 \mathrm{~h}$ & [101] \\
\hline
\end{tabular}

Tanaka et al. developed a glucose monitoring system based on the yeast cell surface display of a fluorescent protein [95]. GFP was fused with the C-terminal half of $\alpha$-agglutinin for surface display on Saccharomyces cerevisiae (S. cerevisiae). Using the glucose-inducible promoter, GAPDH, expression of the surface-displayed GFP was controlled for glucose monitoring by fluorescence measurement using whole yeast cells. This yeast cell surface display system was modified by adding another surface displaying vector [96]. The blue fluorescent protein (BFP)-displaying vector with the UPR-ICL promoter was activated in the absence of glucose. By co-transformation of the two surface-displayed vectors in S. cerevisiae, the green fluorescence arising in the presence of glucose was monitored, whereas the emission of the BFP was restored after the consumption of glucose. A similar system was utilized to monitor phosphate and ammonium ions [97]. Enhanced cyan blue fluorescent protein (ECFP) and enhanced yellow fluorescent protein (EYFP) sequences were inserted into surface-displaying vectors with PHO5 and MEP2 promoters, respectively. In those studies, proteins were surface-displayed on yeast cells when their fluorescence was induced by the monitoring target. Thus, yeast cell surface display technology was applied to fluorescence biosensors for monitoring the presence of a target.

A real-time monitoring system for bioprocessing using yeast cell surface display (Figure 4a) was also developed [98]. In that study, enhanced GFP (EGFP) was fused with agglutinin for the surface display, and the galactose-inducible promoter GAL1 was selected to regulate gene expression. The monitoring of foreign protein production ( $\beta$-galactosidase for intracellular expression and human interferon-omega for extracellular expression) was established by simultaneous surface display of EGFP as a reporter with the same promoter. 


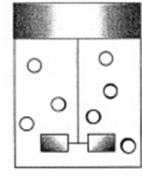

Extracellular Molecular Data



toum

Cell Surface Engineering

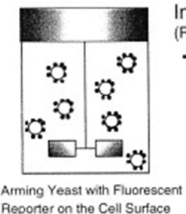

Intracellular Molecular Data (Promoter Activation : Gene Expression Level)

Extracellular Molecular Data

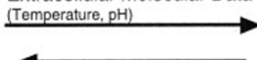

Control



(a)
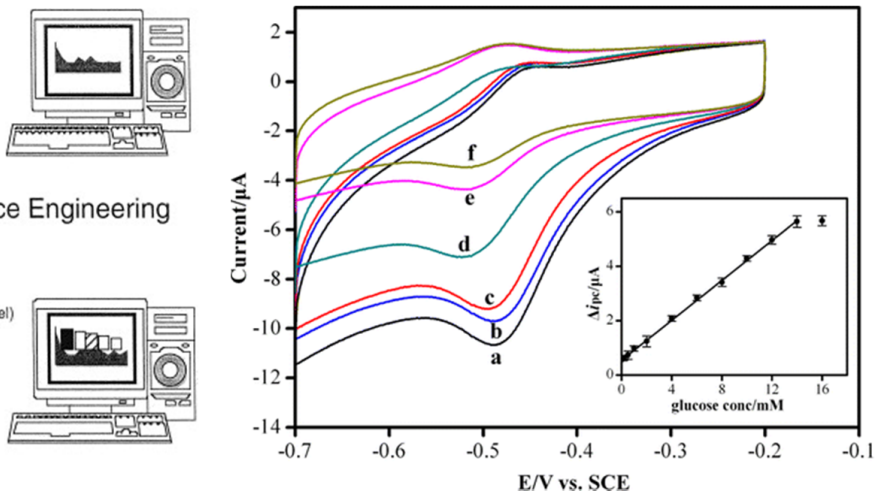

(b)

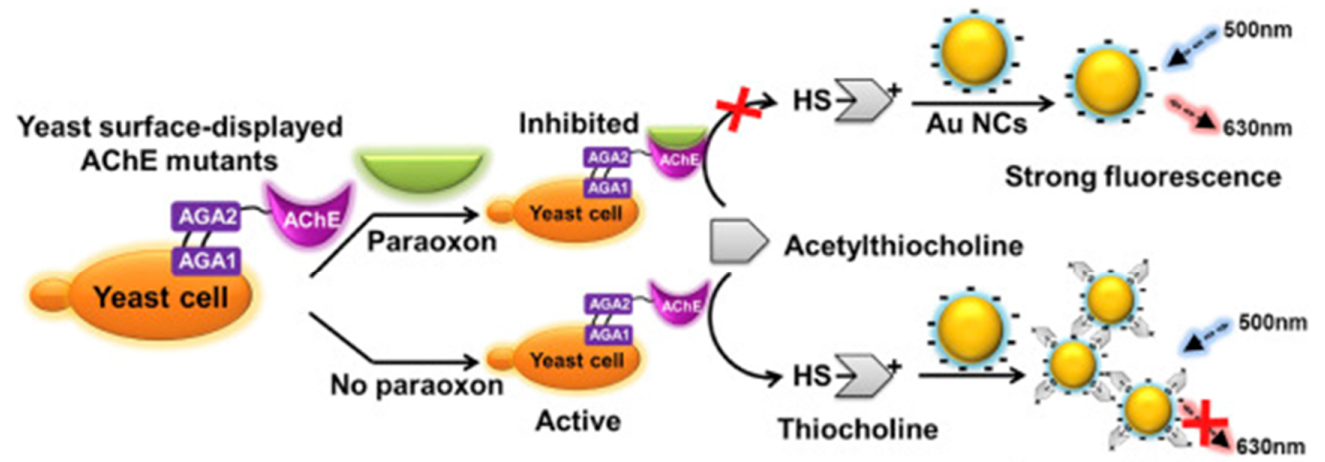

Aggregation-induced fluorescence quenching

(c)

Figure 4. Biosensors based on yeast cell surface display. (a) Biomonitoring system based on surface display technology. Reproduced with permission [98]. Copyright (2003) Elsevier. (b) Electrochemical glucose biosensing based on glucose oxidase surface displaying yeasts. For the biosensing, glucose was spiked in PBS with different concentrations: 0.0 (a), 0.1 (b), 0.5 (c), 2.0 (d), 8.0 (e), and 12.0 (f) mM. Reproduced with permission [99]. Copyright (2013) American Chemical Society. (c) Paraoxon biosensing using AChE surface displaying yeasts. Reproduced with permission [101]. Copyright (2018) Elsevier.

Nakamura et al. displayed IgG-binding Z-domains on the surface of yeast cells by fusion with the C-terminal half of $\alpha$-agglutinin [102]. ZZ-domain surface displaying yeast cells can be utilized as a solid support for enzyme-linked immunosorbent assay (ELISA) to detect human serum albumin and can be used for the affinity purification of IgG. That study demonstrated a ZZ-domain fused with EGFP and discussed the capability to study interactions, biosensing, and immunoassays [103]. The se systems have great potential for application to biosensors, as described in Section 3.1.

Glucose oxidase (GOx) was surface-displayed on S. cerevisiae as a whole-cell biocatalyst, and this arming yeast was used as a glucose biosensor [99]. GOx was displayed on yeast cells as a fusion protein with $\alpha$-agglutinin as an anchor motif. The surface-displayed GOx was confirmed to have good $\mathrm{pH}$ stability and thermostability with high specificity. GOx surface-displaying cells were immobilized on a GCE for electrochemical measurement. For glucose biosensing by cyclic voltammetry, the fabricated glucose biosensor showed a linear response range of $0.1-14 \mathrm{mM}$ and LOD of $0.05 \mathrm{mM}$ (Figure 4b). Furthermore, in real sample measurements, the developed biosensor showed good accuracy within 7\% of the relative standard deviation.

Yeast surface display technology was applied to OP biosensing. Liang et al. expressed active acetylcholinesterase (AChE) through $\alpha$-agglutinin as an anchor motif on the surface of yeast cells 
for spectrophotometric biosensing [100]. The surface-displayed AChE hydrolyzes acetylthiocholine chloride (ATCl) to form thiocholine, and this thiocholine reacts with 5,5'-dithiobis-2-nitrobenzoic acid (DTNB), which absorbs light at $415 \mathrm{~nm}$. In the presence of OP pesticides such as paraoxon and parathion, the active site of AChE was inhibited, which prevented hydrolysis of ATCl, leading to no colorimetric response. Using the developed spectrophotometric biosensor, the LOD for paraoxon and parathion was calculated to be 0.49 and $12.8 \mathrm{nM}$ with linear detection ranges of $1.8 \mathrm{nM}-36.3 \mu \mathrm{M}$ and 17-34.4 $\mu \mathrm{M}$, respectively. The fabricated biosensor was also confirmed to be capable of measuring analytes in tap water, seawater, and sewage. Very recently, AChE surface-displaying yeast cells were utilized to fabricate a fluorescence biosensor [101]. As shown in Figure 4c, after hydrolysis of ATCl by the surface-displayed AChE, positively charged thiocholine with thiol groups was generated, leading to aggregation of gold nanoclusters (AuNCs) through electrostatic interactions, and the aggregated AuNCs quenched the fluorescence signal. For paraoxon detection, the LOD was calculated to be $3.3 \times 10^{-14} \mathrm{M}$ with a linear range of $1.0 \times 10^{-13}-1.0 \times 10^{-10} \mathrm{M}$.

\section{Conclusions and Perspectives}

In this review, various types of surface display technologies such as phage display, bacterial surface display, and yeast cell surface display were discussed. Phage display is a useful tool for the display of libraries because of its high diversity. By using phage display and biopanning, affinity proteins can be screened with specific targets, and screened proteins or screened proteins displaying phage particles have been applied to the construction of molecular recognition layers. Examples of the application of phage display to biosensors are summarized in Table 1. In addition, other advantage of phage display is that phage can display several different targets. It means that phage can display both affinity protein in minor coat protein to immobilization of phage particle on the sensor surface and recognition protein in major coat protein to capture analytes. Phage display technology for the biosensor application will require more diversity and stability of displayed library to select new recognition molecules with high affinity.

The expression of larger proteins on the surface of phage particles is limited; thus, bacterial cells are utilized for expression of these proteins. By using bacterial cells, not only affinity proteins, but also active enzymes, can be displayed on the outer surface of the cells. Affinity proteins such as Z-domains can be applied to the construction of the immunoaffinity layer for biosensors. Surface-displayed active enzymes on bacterial cells may also be useful for the construction of a molecular recognition layer. In particular, the surface display of oxidoreductase is suitable for the fabrication of electrochemical biosensors. Bacterial surface displays and their biosensor applications are summarized in Table 2. Bacteria cells can proliferate by binary fission and single bacteria cell can be identified and sorted using the flow cytometry. It means that bacteria surface display system can offer easier process of screening than phage display. In addition, there is no size limitation of target protein in bacterial surface display. From these reason, bacterial surface display of peptides or antibodies libraries may play an important role in the biosensor applications. Additional advantage of bacterial surface display is that it offers membrane environment to surface displaying targets. Numerous enzymes only have activity in the membrane environment so utilization of these enzymes to the biosensor can be realized by bacterial surface display.

The surface display of a complex eukaryotic protein can be realized by yeast cells. Yeast cell surface display technology is also a good platform for the development of biosensing methods. Various proteins, including fluorescent proteins and enzymes, have been surface displayed on yeast cells and applied in biosensors. A summary of yeast cell surface display-based biosensors is presented in Table 3. In comparison to other surface display systems, yeast cell surface display has distinct merits of safety and ability to express complex eukaryotic proteins. As mentioned above, yeast cells can be used in the food and medicines so yeast cell surface display system can be applied to eatable biosensing systems, in vivo monitoring system, and so on. In addition, enzymatic biosensor utilizing eukaryotic proteins can be realized by yeast cell surface display. 
Overall, this review sheds light on biosensing applications based on surface display technologies and their further potential for biosensor applications.

Funding: This work was supported by a National Research Foundation of Korea (NRF) grant funded by the Korean Government (MSIP) (2019R1I1A3A01058192), Republic of Korea, and Hallym University Research Fund, 2019 (HRF-201902-016).

Conflicts of Interest: The author declares no conflict of interest.

\section{References}

1. Park, M. Orientation Control of the Molecular Recognition Layer for Improved Sensitivity: A Review. BioChip J. 2019, 13, 82-94. [CrossRef]

2. Pyun, J.; Kim, S.; Chung, J. New immobilization method for immunoaffinity biosensors by using thiolated proteins. Anal. Biochem. 2005, 347, 227-233. [CrossRef]

3. Turner, A.; Karube, I.; Wilson, G.S. Biosensors: Fundamentals and Applications; Oxford University Press: Hong Kong, China, 1987.

4. Afzal, A.; Iqbal, N.; Mujahid, A.; Schirhagl, R. Advanced vapor recognition materials for selective and fast responsive surface acoustic wave sensors: A review. Anal. Chim. Acta 2013, 787, 36-49. [CrossRef]

5. Arnau, A. A review of interface electronic systems for AT-cut quartz crystal microbalance applications in liquids. Sensors 2008, 8, 370-411. [CrossRef]

6. Tsouti, V.; Boutopoulos, C.; Zergioti, I.; Chatzandroulis, S. Capacitive microsystems for biological sensing. Biosens. Bioelectron. 2011, 27, 1-11. [CrossRef]

7. Hoa, X.D.; Kirk, A.; Tabrizian, M. Towards integrated and sensitive surface plasmon resonance biosensors: A review of recent progress. Biosens. Bioelectron. 2007, 23, 151-160. [CrossRef]

8. Putzbach, W.; Ronkainen, N.J. Immobilization techniques in the fabrication of nanomaterial-based electrochemical biosensors: A review. Sensors 2013, 13, 4811-4840. [CrossRef]

9. Park, M.; Pyun, J.C.; Jose, J. Orientation and density control of proteins on solid matters by outer membrane coating: Analytical and diagnostic applications. J. Pharm. Biomed. Anal. 2018, 147, 174-184. [CrossRef]

10. Karlsson, R. SPR for molecular interaction analysis: A review of emerging application areas. J. Mol. Recognit. 2004, 17, 151-161. [CrossRef]

11. Tuantranont, A.; Wisitsora-At, A.; Sritongkham, P.; Jaruwongrungsee, K. A review of monolithic multichannel quartz crystal microbalance: A review. Anal. Chim. Acta 2011, 687, 114-128. [CrossRef]

12. Suhito, I.R.; Angeline, N.; Kim, T.-H. Nanomaterial-modified hybrid platforms for precise electrochemical detection of dopamine. BioChip J. 2019, 13, 20-29. [CrossRef]

13. Lee, S.; Choi, I. Fabrication Strategies of 3D Plasmonic Structures for SERS. BioChip J. 2019, 13, 30-42. [CrossRef]

14. Liu, Q.; Wang, J.; Boyd, B.J. Peptide-based biosensors. Talanta 2015, 136, 114-127. [CrossRef]

15. Mross, S.; Pierrat, S.; Zimmermann, T.; Kraft, M. Microfluidic enzymatic biosensing systems: A review. Biosens. Bioelectron. 2015, 70, 376-391. [CrossRef]

16. Yousefi, M.; Dehghani, S.; Nosrati, R.; Zare, H.; Evazalipour, M.; Mosafer, J.; Tehrani, B.S.; Pasdar, A.; Mokhtarzadeh, A.; Ramezani, M. Aptasensors as a new sensing technology developed for the detection of MUC1 mucin: A review. Biosens. Bioelectron. 2019, 130,1-19. [CrossRef]

17. Felix, F.S.; Angnes, L. Electrochemical immunosensors-A powerful tool for analytical applications. Biosens. Bioelectron. 2018, 102, 470-478. [CrossRef]

18. Wang, W.; Chen, C.; Qian, M.; Zhao, X.S. Aptamer biosensor for protein detection using gold nanoparticles. Anal. Biochem. 2008, 373, 213-219. [CrossRef]

19. Rishpon, J.; Ivnitski, D. An amperometric enzyme-channeling immunosensor. Biosens. Bioelectron. 1997, 12, 195-204. [CrossRef]

20. Sung, J.H.; Koo, J.; Shuler, M.L. Mimicking the Human Physiology with Microphysiological Systems (MPS). BioChip J. 2019, 13, 115-126. [CrossRef]

21. Lewis, R.; Barrett-Jolley, R. Changes in membrane receptors and ion channels as potential biomarkers for osteoarthritis. Front. Physiol. 2015, 6, 357. [CrossRef] 
22. Kondo, A.; Ueda, M. Yeast cell-surface display—applications of molecular display. Appl. Microbiol. Biotechnol. 2004, 64, 28-40. [CrossRef]

23. Cho, W.; Stahelin, R.V. Membrane-protein interactions in cell signaling and membrane trafficking. Annu. Rev. Biophys. Biomol. Struct. 2005, 34, 119-151. [CrossRef]

24. Benallal, M.; Anner, B.M. Identification of organ-specific glycosylation of a membrane protein in two tissues using lectins. Experientia 1994, 50, 664-668. [CrossRef]

25. Almén, M.S.; Nordström, K.J.; Fredriksson, R.; Schiöth, H.B. Mapping the human membrane proteome: A majority of the human membrane proteins can be classified according to function and evolutionary origin. BMC Biol. 2009, 7, 50. [CrossRef]

26. Nakane, Y.; Kubo, I. Layer-by-layer of liposomes and membrane protein as a recognition element of biosensor. Thin Solid Films 2009, 518, 678-681. [CrossRef]

27. Jose, J.; Maas, R.M.; Teese, M.G. Autodisplay of enzymes-Molecular basis and perspectives. J. Biotechnol. 2012, 161, 92-103. [CrossRef]

28. Chen, W.; Georgiou, G. Cell-surface display of heterologous proteins: From high-throughput screening to environmental applications. Biotechnol. Bioeng. 2002, 79, 496-503. [CrossRef]

29. Lee, S.Y.; Choi, J.H.; Xu, Z. Microbial cell-surface display. Trends Biotechnol. 2003, 21, 45-52. [CrossRef]

30. Grabherr, R.; Ernst, W. The baculovirus expression system as a tool for generating diversity by viral surface display. Comb. Chem. High Throughput Screen. 2001, 4, 185-192. [CrossRef]

31. Smith, G.P. Filamentous fusion phage: Novel expression vectors that display cloned antigens on the virion surface. Science 1985, 228, 1315-1317. [CrossRef]

32. Petrenko, V.A.; Vodyanoy, V.J. Phage display for detection of biological threat agents. J. Microbiol. Methods 2003, 53, 253-262. [CrossRef]

33. Giordano, R.J.; Cardó-Vila, M.; Lahdenranta, J.; Pasqualini, R.; Arap, W. Biopanning and rapid analysis of selective interactive ligands. Nat. Med. 2001, 7, 1249-1253. [CrossRef]

34. Smith, G.P.; Petrenko, V.A. Phage display. Chem. Rev. 1997, 97, 391-410. [CrossRef]

35. Bozovičar, K.; Bratkovič, T. Evolving a Peptide: Library Platforms and Diversification Strategies. Int. J. Mol. Sci. 2020, 21, 215. [CrossRef]

36. Peltomaa, R.; Benito-Peña, E.; Barderas, R.; Moreno-Bondi, M.C. Phage Display in the Quest for New Selective Recognition Elements for Biosensors. ACS Omega 2019, 4, 11569-11580. [CrossRef]

37. Shi, F.; Gan, L.; Wang, Y.; Wang, P. Impedimetric biosensor fabricated with affinity peptides for sensitive detection of Escherichia coli O157:H7. Biotechnol. Lett. 2020, 42, 825-832. [CrossRef]

38. Wu, J.; Cropek, D.M.; West, A.C.; Banta, S. Development of a troponin I biosensor using a peptide obtained through phage display. Anal. Chem. 2010, 82, 8235-8243. [CrossRef]

39. Wu, J.; Park, J.P.; Dooley, K.; Cropek, D.M.; West, A.C.; Banta, S. Rapid development of new protein biosensors utilizing peptides obtained via phage display. PLoS ONE 2011, 6, e24948. [CrossRef]

40. Liu, P.; Han, L.; Wang, F.; Petrenko, V.A.; Liu, A. Gold nanoprobe functionalized with specific fusion protein selection from phage display and its application in rapid, selective and sensitive colorimetric biosensing of Staphylococcus aureus. Biosens. Bioelectron. 2016, 82, 195-203. [CrossRef]

41. Lee, K.Y.; Byeon, H.H.; Jang, C.; Choi, J.H.; Choi, I.S.; Jung, Y.; Kim, W.; Chang, J.; Yi, H. Hydrodynamic Assembly of Conductive Nanomesh of Single-Walled Carbon Nanotubes Using Biological Glue. Adv. Mater. 2015, 27, 922-928. [CrossRef]

42. Lee, S.W.; Lee, K.Y.; Song, Y.W.; Choi, W.K.; Chang, J.; Yi, H. Direct electron transfer of enzymes in a biologically assembled conductive nanomesh enzyme platform. Adv. Mater. 2016, 28, 1577-1584. [CrossRef]

43. Nanduri, V.; Sorokulova, I.B.; Samoylov, A.M.; Simonian, A.L.; Petrenko, V.A.; Vodyanoy, V. Phage as a molecular recognition element in biosensors immobilized by physical adsorption. Biosens. Bioelectron. 2007, 22, 986-992. [CrossRef] [PubMed]

44. Nanduri, V.; Bhunia, A.K.; Tu, S.-I.; Paoli, G.C.; Brewster, J.D. SPR biosensor for the detection of L. monocytogenes using phage-displayed antibody. Biosens. Bioelectron. 2007, 23, 248-252. [CrossRef] [PubMed]

45. Park, J.P.; Cropek, D.M.; Banta, S. High affinity peptides for the recognition of the heart disease biomarker troponin I identified using phage display. Biotechnol. Bioeng. 2010, 105, 678-686. [CrossRef] [PubMed]

46. Paoli, G.C.; Chen, C.-Y.; Brewster, J.D. Single-chain Fv antibody with specificity for Listeria monocytogenes. J. Immunol. Methods 2004, 289, 147-155. [CrossRef] 
47. Georgiou, G.; Stathopoulos, C.; Daugherty, P.S.; Nayak, A.R.; Iverson, B.L.; Curtiss, R., 3rd. Display of heterologous proteins on the surface of microorganisms: From the screening of combinatorial libraries to live recombinant vaccines. Nat. Biotechnol. 1997, 15, 29-34. [CrossRef]

48. Little, M.; Fuchs, P.; Breitling, F.; Dübel, S. Bacterial surface presentation of proteins and peptides: An alternative to phage technology? Trends Biotechnol. 1993, 11, 3-5. [CrossRef]

49. van Bloois, E.; Winter, R.T.; Kolmar, H.; Fraaije, M.W. Decorating microbes: Surface display of proteins on Escherichia coli. Trends Biotechnol. 2011, 29, 79-86. [CrossRef]

50. Maurer, J.; Jose, J.; Meyer, T.F. Autodisplay: One-component system for efficient surface display and release of soluble recombinant proteins from Escherichia coli. J. Bacteriol. 1997, 179, 794-804. [CrossRef]

51. Ståhl, S.; Uhlén, M. Bacterial surface display: Trends and progress. Trends Biotechnol. 1997, 15, $185-192$. [CrossRef]

52. Sørensen, H.P.; Mortensen, K.K. Soluble expression of recombinant proteins in the cytoplasm of Escherichia coli. Microb. Cell Fact. 2005, 4, 1. [CrossRef] [PubMed]

53. Löfblom, J. Bacterial display in combinatorial protein engineering. Biotechnol. J. 2011, 6, 1115-1129. [CrossRef] [PubMed]

54. Coico, R. Gram staining. Curr. Protoc. Microbiol. 2006, 1, A.3C.1-A.3C.2. [CrossRef]

55. Saleem, M.; Brim, H.; Hussain, S.; Arshad, M.; Leigh, M. Perspectives on microbial cell surface display in bioremediation. Biotechnol. Adv. 2008, 26, 151-161. [CrossRef] [PubMed]

56. Xu, Z.; Lee, S.Y. Display of Polyhistidine Peptides on theEscherichia coli Cell Surface by Using Outer Membrane Protein C as an Anchoring Motif. Appl. Environ. Microbiol. 1999, 65, 5142-5147. [CrossRef]

57. Lång, H. Outer membrane proteins as surface display systems. Int. J. Med. Microbiol. 2000, 290, 579-585. [CrossRef]

58. Klemm, P.; Schembri, M.A. Fimbriae assisted bacterial surface display of heterologous peptides. Int. J. Med. Microbiol. 2000, 290, 215-221. [CrossRef]

59. Westerlund-Wikström, B. Peptide display on bacterial flagella: Principles and applications. Int. J. Med. Microbiol. 2000, 290, 223-230. [CrossRef]

60. De Keyzer, J.; Van Der Does, C.; Driessen, A. The bacterial translocase: A dynamic protein channel complex. Cell. Mol. Life Sci. 2003, 60, 2034-2052. [CrossRef]

61. Park, M.; Pyun, J.C.; Akter, H.; Nguyen, B.T.; Kang, M.J. Evaluation of a specific diagnostic marker for rheumatoid arthritis based on cyclic citrullinated peptide. J. Pharm. Biomed. Anal. 2015, 115, 107-113. [CrossRef]

62. Mulchandani, A.; Mulchandani, P.; Kaneva, I.; Chen, W. Biosensor for direct determination of organophosphate nerve agents using recombinant Escherichia coli with surface-expressed organophosphorus hydrolase. 1. Potentiometric microbial electrode. Anal. Chem. 1998, 70, 4140-4145. [CrossRef] [PubMed]

63. Tang, X.; Zhang, T.; Liang, B.; Han, D.; Zeng, L.; Zheng, C.; Li, T.; Wei, M.; Liu, A. Sensitive electrochemical microbial biosensor for p-nitrophenylorganophosphates based on electrode modified with cell surface-displayed organophosphorus hydrolase and ordered mesopore carbons. Biosens. Bioelectron. 2014, 60, 137-142. [CrossRef] [PubMed]

64. Liang, B.; Li, L.; Tang, X.; Lang, Q.; Wang, H.; Li, F.; Shi, J.; Shen, W.; Palchetti, I.; Mascini, M. Microbial surface display of glucose dehydrogenase for amperometric glucose biosensor. Biosens. Bioelectron. 2013, 45, 19-24. [CrossRef] [PubMed]

65. Liang, B.; Zhang, S.; Lang, Q.; Song, J.; Han, L.; Liu, A. Amperometric L-glutamate biosensor based on bacterial cell-surface displayed glutamate dehydrogenase. Anal. Chim. Acta 2015, 884, 83-89. [CrossRef] [PubMed]

66. Zhang, Z.; Liu, J.; Fan, J.; Wang, Z.; Li, L. Detection of catechol using an electrochemical biosensor based on engineered Escherichia coli cells that surface-display laccase. Anal. Chim. Acta 2018, 1009, 65-72. [CrossRef]

67. Park, T.J.; Zheng, S.; Kang, Y.J.; Lee, S.Y. Development of a whole-cell biosensor by cell surface display of a gold-binding polypeptide on the gold surface. FEMS Microbiol. Lett. 2009, 293, 141-147. [CrossRef]

68. Ravikumar, S.; Ganesh, I.; Yoo, I.-K.; Hong, S.H. Construction of a bacterial biosensor for zinc and copper and its application to the development of multifunctional heavy metal adsorption bacteria. Process Biochem. 2012, 47, 758-765. [CrossRef] 
69. Jose, J.; Chung, J.-W.; Jeon, B.-J.; Maas, R.M.; Nam, C.-H.; Pyun, J.-C. Escherichia coli with autodisplayed Z-domain of protein A for signal amplification of SPR biosensor. Biosens. Bioelectron. 2009, 24, 1324-1329. [CrossRef]

70. Lee, E.-H.; Yoo, G.; Jose, J.; Kang, M.-J.; Song, S.-M.; Pyun, J.-C. SPR biosensor based on immobilized E. coli cells with autodisplayed Z-domains. BioChip J. 2012, 6, 221-228. [CrossRef]

71. Jose, J.; Park, M.; Pyun, J.C. E. coli outer membrane with autodisplayed Z-domain as a molecular recognition layer of SPR biosensor. Biosens. Bioelectron. 2010, 25, 1225-1228. [CrossRef]

72. Park, M.; Jose, J.; Pyun, J.-C. SPR biosensor by using E. coli outer membrane layer with autodisplayed Z-domains. Sens. Actuators B Chem. 2011, 154, 82-88. [CrossRef]

73. Kronqvist, N.; Löfblom, J.; Jonsson, A.; Wernérus, H.; Ståhl, S. A novel affinity protein selection system based on staphylococcal cell surface display and flow cytometry. Protein Eng. Des. Sel. 2008, 21, $247-255$. [CrossRef] [PubMed]

74. Kronqvist, N.; Malm, M.; Göstring, L.; Gunneriusson, E.; Nilsson, M.; Höidén Guthenberg, I.; Gedda, L.; Frejd, F.Y.; Ståhl, S.; Löfblom, J. Combining phage and staphylococcal surface display for generation of ErbB3-specific Affibody molecules. Protein Eng. Des. Sel. 2011, 24, 385-396. [CrossRef]

75. Richins, R.D.; Kaneva, I.; Mulchandani, A.; Chen, W. Biodegradation of organophosphorus pesticides by surface-expressed organophosphorus hydrolase. Nat. Biotechnol. 1997, 15, 984-987. [CrossRef] [PubMed]

76. Tang, X.; Liang, B.; Yi, T.; Manco, G.; Palchetti, I.; Liu, A. Corrigendum to "Cell surface display of organophosphorus hydrolase for sensitive spectrophotometric detection of p-nitrophenol substituted organophosphates" [Enzyme Microb. Technol. 55 (2014) 107-112]. Enzyme Microb. Technol. 2014, 60, 80. [CrossRef]

77. Jose, J.; Meyer, T.F. The autodisplay story, from discovery to biotechnical and biomedical applications. Microbiol. Mol. Biol. Rev. 2007, 71, 600-619. [CrossRef]

78. Jose, J. Autodisplay: Efficient bacterial surface display of recombinant proteins. Appl. Microbiol. Biotechnol. 2006, 69, 607-614. [CrossRef]

79. Park, M.; Jose, J.; Thommes, S.; Kim, J.I.; Kang, M.J.; Pyun, J.C. Autodisplay of streptavidin. Enzyme Microb. Technol. 2011, 48, 307-311. [CrossRef]

80. Jose, J.; Park, M.; Pyun, J.C. Highly sensitive immunoassay based on E. coli with autodisplayed Z-domain. Anal. Chim. Acta 2010, 667, 113-118. [CrossRef]

81. Nilsson, B.; Moks, T.; Jansson, B.; Abrahmsen, L.; Elmblad, A.; Holmgren, E.; Henrichson, C.; Jones, T.A.; Uhlen, M. A synthetic IgG-binding domain based on staphylococcal protein A. Protein Eng. Design Sel. 1987, 1, 107-113. [CrossRef]

82. Park, M.; Yoo, G.; Bong, J.H.; Jose, J.; Kang, M.J.; Pyun, J.C. Isolation and characterization of the outer membrane of Escherichia coli with autodisplayed Z-domains. Biochim. Biophys. Acta 2015, 1848, 842-847. [CrossRef]

83. Park, M.; Jose, J.; Pyun, J.-C. Hypersensitive immunoassay by using Escherichia coli outer membrane with autodisplayed Z-domains. Enzyme Microb. Technol. 2010, 46, 309-314. [CrossRef]

84. Jeon, D.; Pyun, J.C.; Jose, J.; Park, M. A Regenerative Immunoaffinity Layer Based on the Outer Membrane of Z-Domains Autodisplaying, E. coli for Immunoassays and Immunosensors. Sensors 2018, 18, 4030. [CrossRef]

85. Shockman, G.D.; Barren, J.F. Structure, function, and assembly of cell walls of gram-positive bacteria. Annu. Rev. Microbiol. 1983, 37, 501-527. [CrossRef] [PubMed]

86. Ståahl, S.; Robert, A.; Gunneriusson, E.; Wernérus, H.; Cano, F.; Liljeqvist, S.; Hansson, M.; Nguyen, T.N.; Samuelson, P. Staphylococcal surface display and its applications. Int. J. Med. Microbiol. 2000, 290, 571-577. [CrossRef]

87. Hansson, M.; Samuelson, P.; Gunneriusso, E.; Stahl, S. Surface display on gram positive bacteria. Comb. Chem. High Throughput Screen. 2001, 4, 171-184. [CrossRef] [PubMed]

88. Fleet, G. Cell walls. In The Yeasts, vol 4. Organelles; Rose, A.H., Harrison, J.S., Eds.; Academic: London, UK, 1991.

89. Chen, X. Yeast cell surface display: An efficient strategy for improvement of bioethanol fermentation performance. Bioengineered 2017, 8, 115-119. [CrossRef]

90. Kukuruzinska, M.; Bergh, M.; Jackson, B. Protein glycosylation in yeast. Annu. Rev. Biochem. 1987, 56, 915-944. [CrossRef] 
91. Hamilton, S.R.; Gerngross, T.U. Glycosylation engineering in yeast: The advent of fully humanized yeast. Curr. Opin. Biotechnol. 2007, 18, 387-392. [CrossRef]

92. Han, L.; Zhao, Y.; Cui, S.; Liang, B. Redesigning of microbial cell surface and its application to whole-cell biocatalysis and biosensors. Appl. Biochem. Biotechnol. 2018, 185, 396-418. [CrossRef] [PubMed]

93. Kuroda, K.; Ueda, M. Arming technology in yeast-Novel strategy for whole-cell biocatalyst and protein engineering. Biomolecules 2013, 3, 632-650. [CrossRef] [PubMed]

94. Kuroda, K.; Ueda, M. Generation of arming yeasts with active proteins and peptides via cell surface display system: Cell surface engineering, bio-arming technology. In Yeast Metabolic Engineering; Springer: Berlin/Heidelberg, Germany, 2014; pp. 137-155.

95. Ye, K.; Shibasaki, S.; Ueda, M.; Murai, T.; Kamasawa, N.; Osumi, M.; Shimizu, K.; Tanaka, A. Construction of an engineered yeast with glucose-inducible emission of green fluorescence from the cell surface. Appl. Microbiol. Biotechnol. 2000, 54, 90-96. [CrossRef] [PubMed]

96. Shibasaki, S.; Ueda, M.; Ye, K.; Shimizu, K.; Kamasawa, N.; Osumi, M.; Tanaka, A. Creation of cell surface-engineered yeast that display different fluorescent proteins in response to the glucose concentration. Appl. Microbiol. Biotechnol. 2001, 57, 528-533. [PubMed]

97. Shibasaki, S.; Ninomiya, Y.; Ueda, M.; Iwahashi, M.; Katsuragi, T.; Tani, Y.; Harashima, S.; Tanaka, A. Intelligent yeast strains with the ability to self-monitor the concentrations of intra-and extracellular phosphate or ammonium ion by emission of fluorescence from the cell surface. Appl. Microbiol. Biotechnol. 2001, 57, 702-707.

98. Shibasaki, S.; Tanaka, A.; Ueda, M. Development of combinatorial bioengineering using yeast cell surface display_order-made design of cell and protein for bio-monitoring. Biosens. Bioelectron. 2003, 19, 123-130. [CrossRef]

99. Wang, H.; Lang, Q.; Li, L.; Liang, B.; Tang, X.; Kong, L.; Mascini, M.; Liu, A. Yeast surface displaying glucose oxidase as whole-cell biocatalyst: Construction, characterization, and its electrochemical glucose sensing application. Anal. Chem. 2013, 85, 6107-6112. [CrossRef]

100. Liang, B.; Wang, G.; Yan, L.; Ren, H.; Feng, R.; Xiong, Z.; Liu, A. Functional cell surface displaying of acetylcholinesterase for spectrophotometric sensing organophosphate pesticide. Sens. Actuators B Chem. 2019, 279, 483-489. [CrossRef]

101. Liang, B.; Han, L. Displaying of acetylcholinesterase mutants on surface of yeast for ultra-trace fluorescence detection of organophosphate pesticides with gold nanoclusters. Biosens. Bioelectron. 2020, 148, 111825. [CrossRef]

102. Nakamura, Y.; Shibasaki, S.; Ueda, M.; Tanaka, A.; Fukuda, H.; Kondo, A. Development of novel whole-cell immunoadsorbents by yeast surface display of the IgG-binding domain. Appl. Microbiol. Biotechnol. 2001, 57, 500-505.

103. Shimojyo, R.; Furukawa, H.; Fukuda, H.; Kondo, A. Preparation of yeast strains displaying IgG binding domain $\mathrm{ZZ}$ and enhanced green fluorescent protein for novel antigen detection systems. J. Biosci. Bioeng. 2003, 96, 493-495. [CrossRef]

(C) 2020 by the author. Licensee MDPI, Basel, Switzerland. This article is an open access article distributed under the terms and conditions of the Creative Commons Attribution (CC BY) license (http://creativecommons.org/licenses/by/4.0/). 